\title{
Palaeoclimatic and biotic changes during the Aalenian (Middle Jurassic) at the southern Laurasian Seaway (Basque-Cantabrian Basin, northern Spain)
}

\author{
Juan J. Gómez ${ }^{\text {a,* }}$, María L. Canales ${ }^{\text {b, Soledad Ureta }}{ }^{\text {b }}$, Antonio Goy ${ }^{\text {b }}$ \\ a Dpto. de Estratigrafia, Facuitad de Ciencias Geológicas (UCM) and Instituto de Geologín Económica (CSIC-UCM), 28040 Madrid, Spain \\ ${ }^{b}$ Dpto. de Paleontología, Facultad de Ciencias Geologicas (UCM) and Instituto de Geologí Económica (CSIC-UCM), 28040 Madrid, Spain
}

Keywords:

Palaeoclimate

Biotic changes

Foraminifers

Ammonoids

Stable isotopes

Palaeoceanography

\section{A B S T R A C T}

The uppermost Toarcian-lowermost Bajocian deposits have been studied in 10 sections located in the western part of the Basque-Cantabrian Basin (northern Spain). The studied 276 successive recorded ammonite assemblages allowed detailed biostratigraphical subdivision and the correlation of the sections at the ammonite zone and subzone scale. The foraminifers were studied in 96 samples and 55 diagenetically screened belemnite rostra were analyzed for $C$ and $O$ isotope.

Facies and thickness distribution of the Aalenian sediments suggest that deposition took place in a nearly symmetrical sub-basin included into an intraplate shallow platform, developed over continental crust, on which flexure was the main control responsible for subsidence and basin evolution.

Noteworthy negative ${ }^{13} C_{\mathrm{bel}}$ excursions, coinciding with seawater temperature changes, were recorded during the Bradfordensis Biochron, around the Concavum-Limitatum biochron boundary, and around the Aalenian-Bajocian boundary. A close relationship between the changes in seawater temperature and the biotic changes observed in the foraminiferal and in the ammonoids assemblages has been evidenced. During

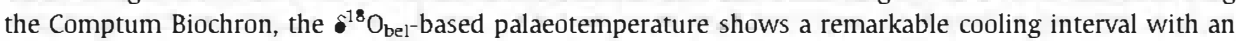
average seawater temperature of $15.7^{\circ} \mathrm{C}$. This cooling favoured the immigration of species of foraminifers that thrived in platforms with colder seawater temperatures located north of the Basque-Cantabrian Basin. As a consequence, a strong increase in the diversity of the foraminiferal assemblages $(28.5 \%$ of first appearances) occurred. This interval also coincides with the highest ammonoid abundance recorded during the Aalenian. A notable increase in temperature with peak values up to $24.3^{\circ} \mathrm{C}$, was measured during the Bradfordensis Biochron. This warming marks the beginning of progressive loss of foraminifer diversity and the decrease in the abundance of ammonoids. However, the increase in the relative abundances of some foraminiferal taxa such as the genus Spirillina during the warming phase is remarkable. Some of the foraminiferal species that had their last occurrence during this interval seem to be immigrants from NW Europe that arrived during the Comptum cooling interval, and that did not survive to rise of the seawater temperature.

Another drop in temperature was recorded during the late Gigantea and the early Concavum biochrons. Coinciding with this cooling interval nearly $20 \%$ of the foraminiferal species disappeared while the ammonoid abundance increased. A new and significant warming episode occurred during the latest Aalenian (Limitatum Biochron), extending to the earliest Bajocian (Discites Biochron). Biotic response to this new $\Delta T$ of $2.5^{\circ} \mathrm{C}$ is remarkable, marking one of the most important crises of the Aalenian. More than $30 \%$ of the foraminiferal species disappeared and no new appearances were recorded. Ammonoids show a decrease in the specimen abundance during the Limitatum-Discites warming, preceding a drastic decrease in the species abundance.

The remarkable biotic changes linked to the variations of seawater temperature recorded in the BasqueCantabrian Basin during the Aalenian, open the possibility that some of these faunal turnovers, specially marked in the benthic foraminifers, were of global extent and mainly forced by climate changes.

\section{Introduction}

The Aalenian (base of the Middle Jurassic) is a particularly interesting geological time interval, due to a major pulse in the opening of the Protoatlantic, through the Laurasian Seaway (Fig. 1a), which led to significant palaeoenvironmental instability in most 


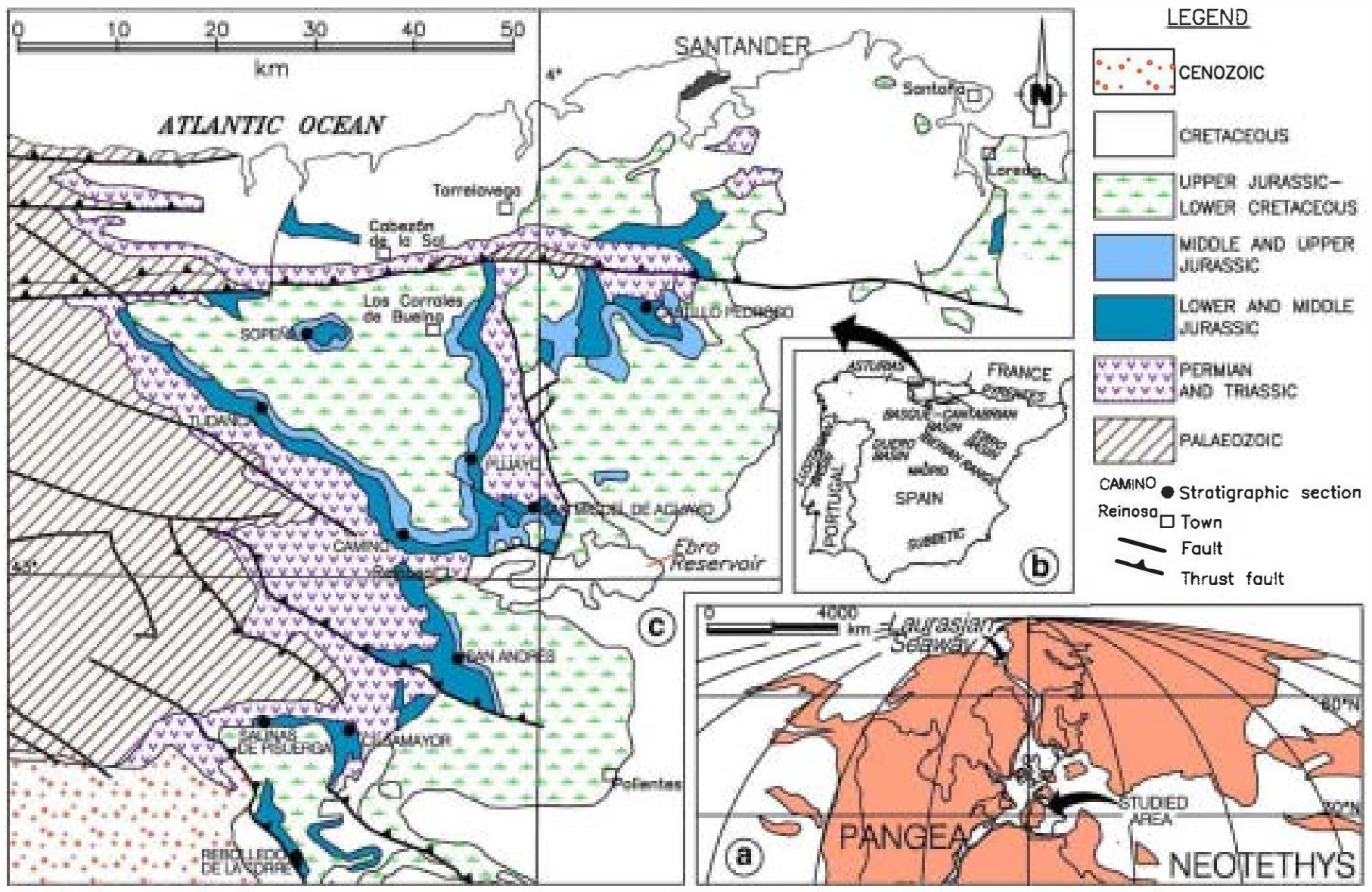

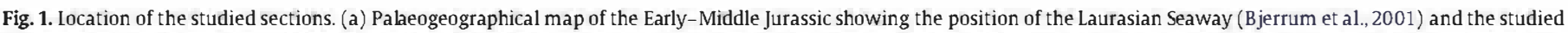

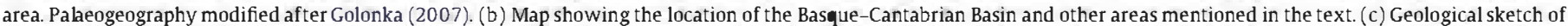
the area containing the Aalenian stratigraphic sections studied.

European platforms. As a response to accelerated fragmentation of Pangea during the Early-Middle Jurassic transition, changes affecting the palaeogeography are reflected in many areas by a highly varying sedimentary record, with differing sea-level changes partly controlled by tectonics (e.g. García-Frank et al., 2008), and by the accompanying changes in the climate and, as a consequence, notable changes in the biota. In many areas of Europe, the Aalenian, or a part of it, is represented by condensed sections, in which stratigraphic gaps are common. Thick expanded sections, containing more complete sedimentary records, can only be studied in a few areas.

The global Aalenian isotope chemostratigraphy and the palaeoclimatic evolution are not well known, due to the scarcity of reliable records preserving the primary seawater signal. The finding of a negative ${ }^{13} \mathrm{C}$ anomaly in bulk rock samples near the AalenianBajocian boundary in southern Spain, associated with an important ammonite turnover event (O'Dogherty et al., 2006), adds further interest to the study of this time interval.

Here we summarize the results of the study of 10 sections comprising uppermost Toarcian-lowermost Bajocian deposits. These sections are located in the westem part of the Basque-Cantabrian Basin, in northem Spain (Fig. 1b, c). The Basque-Cantabrian Basin is an east-west trending fold and thrust belt, considered as the western extension of the Pyrenees (Alonso and Pulgar, 2004). The southwards displacement of the thrust sheets, composed of Mesozoic and Cenozoic deposits (Fig. 1b) is in the order of $15-20 \mathrm{~km}$ in some areas (Serrano Oñate et al., 1989).

The excellent outcrop conditions and the ammonite content of the studied sections have allowed a high-resolution ammonite-based biostratigraphy at the subzone level (Goy and Ureta 1981, 1991, 1994).
Other studies on the ammonites were carried out by Dahm (1965) and Fernández-López et al. (1988) and on the foraminifers by Canales (1992), Canales et al. (1993), Canales and Ureta (1997), Canales (2001) and Gräfe (2005). The analysis of the $\delta^{13} \mathrm{C}$ and $\delta^{18} \mathrm{O}$ values has been based on the collection and study of the belemnite rostra contained in the Aalenian deposits. The curve showing the seawater palaeotemperature variations for this interval has been calculated from the $\delta^{18} \mathrm{O}$ values. Finally, the comparison between the palaeoclimate changes and the stratigraphical distribution of the benthic foraminifers and ammonoids found in this work and the brachiopods distribution cited in the literature, allows analyzing of the relationships between the climate and the biotic changes.

\section{Materials and methods}

Biostratigraphy has been based on the study of 704 specimens of ammonoids from the 276 successive assemblages found in the bed by bed sampling performed in the 10 studied stratigraphical sections. Identification at the species level has been carried out only in the well preserved fossils. The systematic classification proposed by Ureta Gil (1985) has been used for the graphoceratids and the systematics proposed by Martínez (1992) and by Linares and Sandoval (1986. 1996) has been followed for the hammatoceratids, erycitids and other Mediterranean taxa. The taphonomical analysis of the assemblages is aimed at the identification of reworked fossils and the recognition of necroplanktonic drift. To identify the demic or ademic character of the diverse groups of ammonoids, the sexual dimorphism and the growth stages have also been studied. 


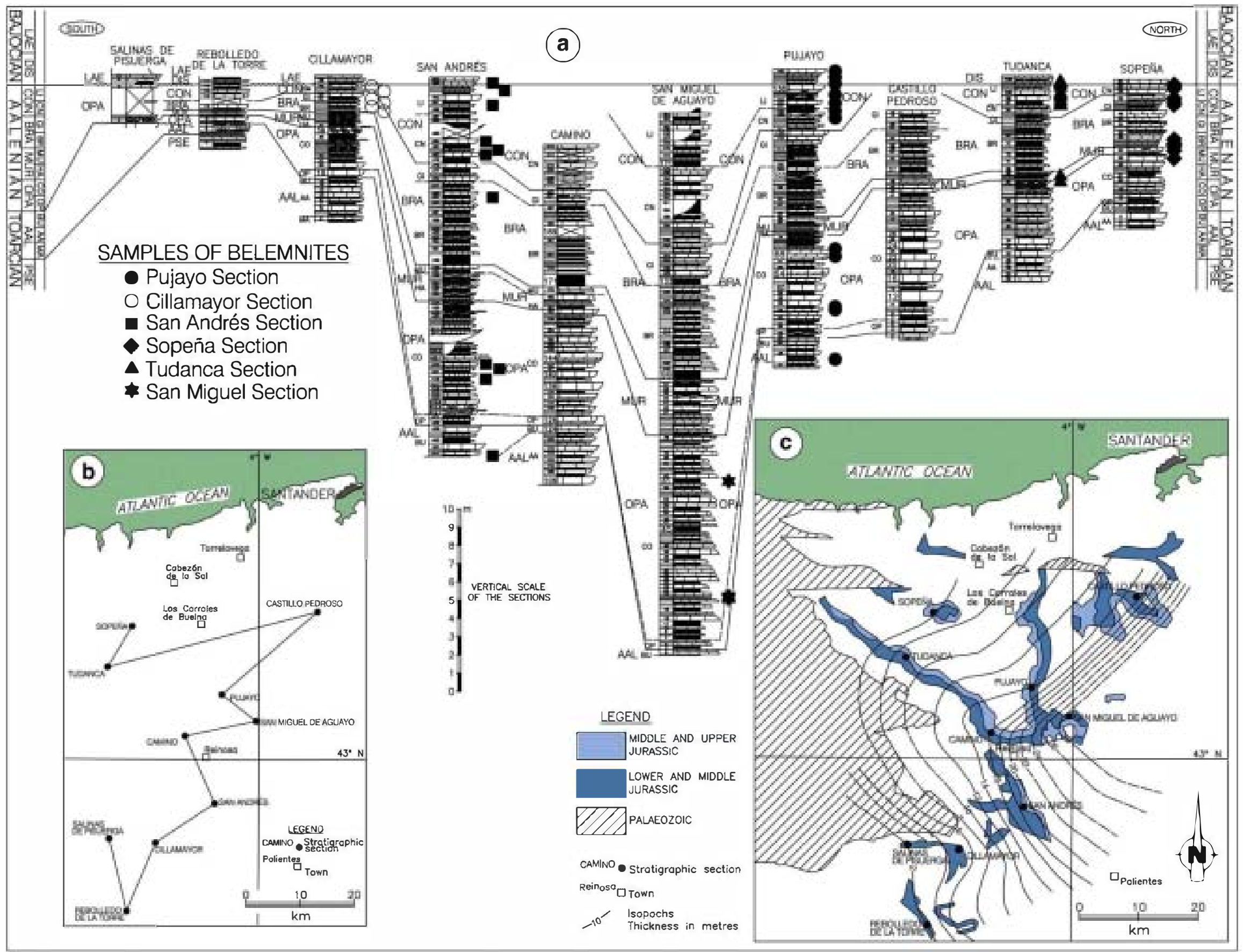


For the study of the foraminiferal fossils, a total of 96 samples from 7 sections were collected, and treated following the method of Ruget et al. (1989). Determination of the obtained 49,720 specimens, at the suprageneric and generic level was carried out by Canales (2001), following the classification of Loeblich and Tappan (1988)

To obtain a primary stable isotope signal of the Aalenian seawater, a total of 55 belemnite rostra were analyzed for $\mathrm{C}$ and $\mathrm{O}$ isotope. For the assessment of possible burial diagenetic alteration, polished samples and thick sections of each belemnite rostra were prepared. The sections were studied under petrographic and cathodoluminescence microscope to test for recrystallization, for burrowing and infilling sediment, as well as for fractures filled with secondary calcite or dolomite. Many of the studied belemnite rostra were non-luminescent, except for the apical line and the outer phragmocone wall. The belemnite guards have been mapped and/or microphotographed marking the zones that show luminescence. Only the non-luminescent portions, which can reasonably be considered as unaltered, were sampled using a microscope-mounted dental drill. None of the studied belemnites were rejected during sampling as all of them showed sufficient areas of non-luminescent calcite as to allow sampling. Analyses were performed in the isotope laboratory of the Michigan University (USA). In all samples, isotope ratios are reported in per mil with respect to the standard Peedee belemnite (PDB). A total of 6 analyses were duplicated and 15 samples of standards were also analyzed. Results of one of the samples were rejected due to unrealistic values. Analytical error was in most cases better than $\pm 0.1 \%$ on both carbon and oxygen isotope ratios.

\section{Stratigraphical succession}

Ammonite assemblages on which the biostigraphical subdivisions are based are described in Goy and Ureta $(1981,1991,1994)$, Canales etal. (1993) and Canales and Ureta (1997). The deposits studied are constituted by an alternation of hemipelagic lime-mudstones and marls belonging to the Castillo Pedroso Formation (Quesada et al., 2005) deposited in a marine external platform environment. Ammonite-based biostratigraphy allows correlation of the sections studied at the zone and subzone scale (Fig. 2a). Lateral variations of the deposits of each biochronostratigraphical subdivision, were also assessed.

\subsection{Uppermost Toarcian}

Uppermost Toarcian deposits, organized in shallowing-upward units, have been recorded in all of the studied sections. However, a local unconformity at the Toarcian-Aalenian boundary led to the absence of the topmost Toarcian (Buckmani Subzone) and the lowermost Aalenian (Opalinum Subzone), in the southwesternmost part of the basin and of the Opalinum Subzone in the Tudanca section (Fig. 2). However, this local hiatus cannot be generalized for the all Basque-Cantabrian Basin as postulated by Aurell et al. (2003) and Quesada et al. (2005). Within the uppermost Toarcian (Aalensis Zone), three subzones (Mactra, Aalensis and Buckmani) have been distinguished. The base of the Mactra Subzone is defined by the First Appearance Datum (FAD) of Pleydellia mactra and/or P. subcompta, the base of the Aalensis Subzone is marked by the FAD of $P$. aalensis, and the base of the Buckmani Subzone by the FAD of $P$. buckmani and/or P. leura.

\subsection{Aalenian}

\subsubsection{Opalinum Zone}

Within the Opalinum Zone, the Opalinum and the suprajacent Comptum subzones are distinguished. The base of the Opalinum Subzone is marked by the FAD of Leioceras opalinum. The zone is commonly recorded in one or two marl-limestone couplets, generally less than $0.5 \mathrm{~m}$ thick.

The Comptum Subzone, marked by the FAD of $L$. comptum, is well represented in all of the studied sections including the southwestern part of the basin. Its maximum thickness $(11 \mathrm{~m})$ is reached in the San Miguel de Aguayo section (Fig. 2). Deposits are organized in shallowing-upward units, occasionally topped by local hard-grounds indicating the presence of local small sedimentary breaks. Wackestone to packstone bioclastic facies, interpreted as tempestites, are locally interbedded in the fine-grained deposits (Cillamayor, Pujayo and Tudanca sections).

\subsubsection{Murchisonae Zone}

The Murchisonae Zone has been subdivided, in some of the studied sections, into the Haugi and the Murchisonae subzones marked by the FADs of Ludwigia haugi and L. murchisonae, respectively. The deposits are organized in shallowing-upwards units, which in many sections are topped by hard-grounds. In most sections, wackestone to packstone bioclastic limestones, containing bivalves, brachiopods and belemnites, are a common lithology chiefly represented in the uppermost parts of the shallowing-upwards units, representing repetitive episodes of tempestites. Maximum thickness of the Murchisonae Zone $(3 \mathrm{~m})$ is reached in the San Miguel de Aguayo area. In the other sections, its thickness is less than $1 \mathrm{~m}$.

\subsubsection{Bradfordensis Zone}

The Bradfordensis Zone has been subdivided into the Bradfordensis and the Gigantea subzones, which can be recognized in all of the studied sections. The Bradfordensis Subzone is one of the thickest Aalenian subzones and its lower boundary is marked by the FAD of Brasilia bradfordensis. The marl layers are more abundant and thicker than in the other subzones. Locally (in the Pujayo section), bioclastic wackestone to packstone facies, containing remains of bivalves, gastropods and belemnites, are interbedded in the marly deposits. In the depocentre area (San Miguel de Aguayo section), the subzone is around $5 \mathrm{~m}$ thick, decreasing north- and southwards (Fig. 2). The lower part of the Bradfordensis Subzone represents a widely distributed transgressive interval, characterized by the presence of deepening-upwards units in the all basin. The upper portion of the subzone is organized in shallowing-upwards units, which pass into the Gigantea Subzone, marked by the FAD of Brasilia gigantea. Locally, interbedded bioclastic limestones, containing remains of bivalves, gastropods and belemnites occur. Maximum thickness is also reached in the San Miguel de Aguayo section, where around $2 \mathrm{~m}$ of sediments was recorded. However, thickness is commonly less than $1 \mathrm{~m}$. The lowermost part of this subzone is composed of shallowing-upwards units, but most of the unit is represented by deepening-upwards units.

\subsubsection{Concavum Zone}

The Concavum Zone, which can only be recognized in the central part of the basin, has been subdivided into the Concavum and the Limitatum subzones. In the Cillamayor section these deposits are very thin and topped by a significant sedimentary break.

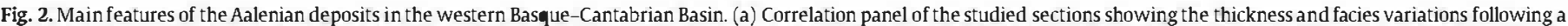

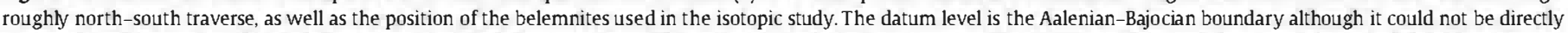

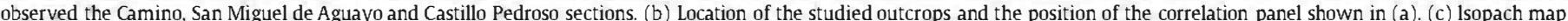

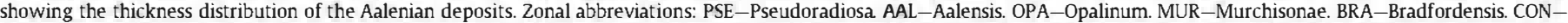

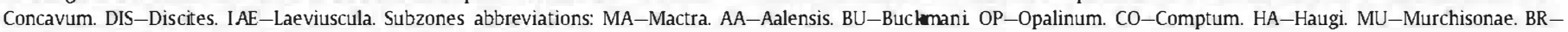
Bradfordensis. GI-Gigantea $\mathrm{CN}-$ Concavum. LI-Limitatum DI-Discites. 


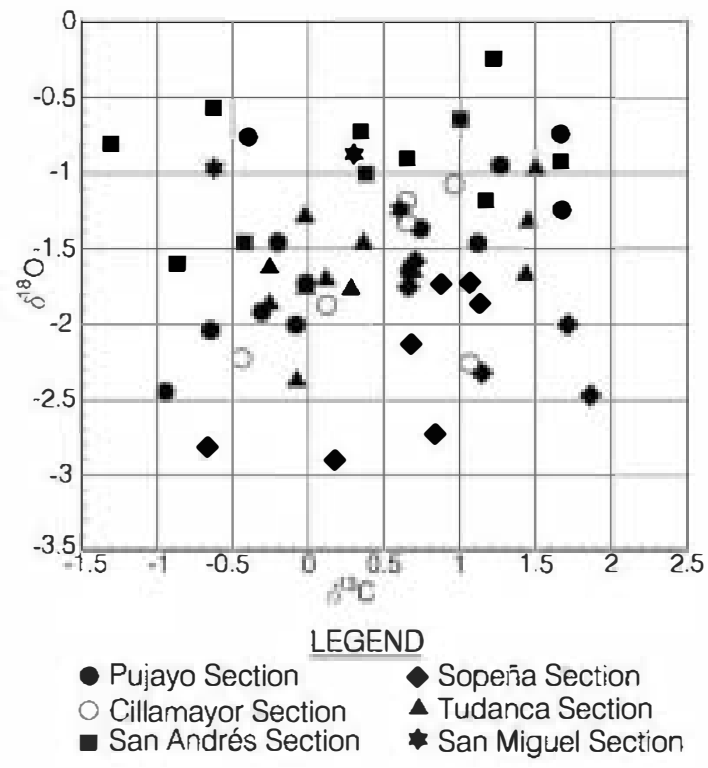

Fig. 3. Cross-plot of $\delta^{18} \mathrm{O}$ against $\delta^{13} \mathrm{C}$ values obtained from belemnite calcite from uppermost Toarcian, Aalenian and lowermost Bajocian samples of the studied sections.

The lower boundary of this Concavum Subzone is marked by the FAD of the Graphoceras concavum or G cornu. The subzone is represented by bioclastic wackestones to packstones, containing fragments of bivalves, belemnites and ammonites. A peculiar bioclastic level, bounded by discontinuities and characterized by the presence of fragmentary sponges, is recorded at the lower part of the Concavum Subzone and constitutes a probably synchronous event at the scale of the whole basin. In the San Miguel de Aguayo section, where the thickness of the zone is the largest (about $4 \mathrm{~m}$ ), the deposits of the Concavum Subzone are organized in deepening and shallowingupwards units, marking the peak transgression at the middle Concavum Subzone.

In the Limitatum Subzone, marked by the FAD of Graphoceras limitatum, bioclastic mudstone to packstone facies are locally present (e.g. Pujayo section). The subzone is locally absent in the southern part of the basin (Cillamayor section) and its maximum thickness is reached in the San Miguel de Aguayo depocentre, where it has more than $4 \mathrm{~m}$ thickness. The lower part of the subzone is represented by deepening-upwards units, the transgressive peak is inferred to be in the middle part of the subzone. The upper part of the subzone is mainly constituted by shallowing-upwards units.

\subsection{Lower Bajocian}

The Lower Bajocian deposits are represented by the Discites and the Laeviuscula zones. The Discites Zone is characterized by the FAD of the genera Sonninia, Hyperlioceras and/ or Reynesella and the Laeviuscula Zone by the FAD of the genus Witchellia. The alternation of limemudstones and marls organized in shallowing-upwards units is the common facies. In the southern part of the basin, the Discites Zone is locally absent and the deposits of the Laeviuscula Zone overlie the deposits of the Concavum Subzone (Cillamayor section, Fig. 2). In the central portion of the basin, the Lower Bajocian deposits overlay the deposits of the uppermost Aalenian (Limitatum Subzone) in normal succession.

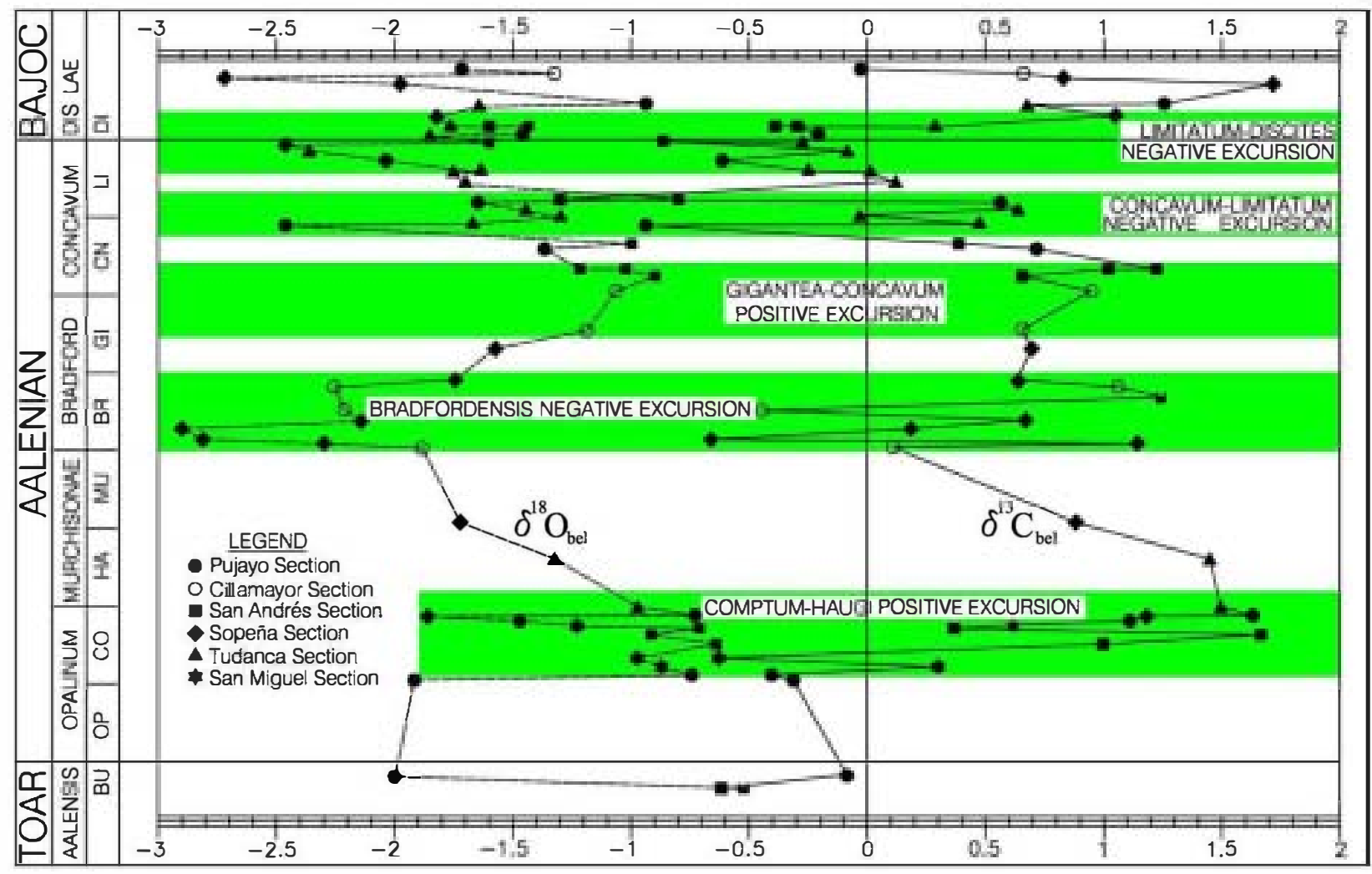

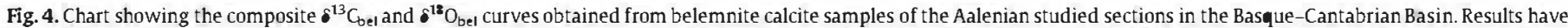

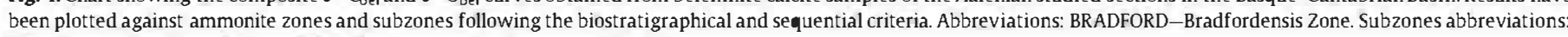
MA-Mactra. For abbreviations of the other zones and subzones see Fig. 2 . 


\section{Stable isotope record and seawater temperature}

Samples of belemnites plotted against the stratigraphic columns are represented in Fig. 2, and a cross-plot of the $\delta^{13} \mathrm{C}_{\text {bel }}$ and $\delta^{18} \mathrm{O}_{\text {bel }}$ values (see Table 1 in Appendix A) is represented in Fig. 3. The lack of correlation between the two values can be interpreted as reflecting the original marine signal with no evidence of important diagenetic overprint. Plotting of the stable isotope values obtained in the 55 diagenetically screened belemnite calcite against the ammonite subzones recognized in the 10 studied sections, allowed to construct the isotope composite curves shown in Fig. 4, on which several well defined $\delta^{13} \mathrm{C}_{\text {bel }}$ and $\delta^{18} \mathrm{O}_{\text {bel }}$ excursions can be observed.

\subsection{The $\delta^{13} C_{\text {bel }}$ curve}

During the latest Toarcian and the earliest Aalenian, $\delta^{13} \mathrm{C}_{\text {bel }}$ values are commonly slightly negative, as observed in other sections of northern and central Spain (Gómez et al., 2008). In the studied sections, these values corresponding to the Buckmani and Opalinum subzones are below the $\delta^{13} C_{\text {bel }}$ average values $(0.47 \%$ ) calculated for the considered time interval.

A first excursion is recorded during the Comptum-Haugi biochrons, where the $\delta^{13} C_{\text {bel }}$ values notably increase, marking a positive shift on which peak values up to $1.66 \%$ o were reached (Fig. 4). During the middle and the late part of the Aalenian several significant well marked excursions are evidenced. First excursion is a noteworthy negative shift, reaching ${ }^{13} C_{\text {bel }}$ values up to $-0.66 \%$ which developed during the Bradfordensis Biochron. The second negative excursion, including $\delta^{13} \mathrm{C}_{\text {bel }}$ peak values of up to $-1.3 \%$, was recorded around the boundary between the Concavum and the Limitatum biochrons. Even positive ${ }^{13} \mathrm{C}_{\mathrm{bel}}$ values were assayed within a short interval of the Limitatum Biochron, a third significant negative $\delta^{13} \mathrm{C}_{\mathrm{bel}}$ excursion, including values up to $-0.87 \%$, has been recorded at the AalenianBajocian transition.

\subsection{The $\delta^{18} \mathrm{O}_{\text {bet }}$ curve}

After the negative $\delta^{18} \mathrm{O}_{\text {bel }}$ values recorded around the ToarcianAalenian transition (up to $-2 \%$ ), a significant excursion towards less negative values occurred during the Comptum and the earliest part of the Haugi biochrons (Fig. 4). Except for some small shifts towards more negative values, average values of $-0.99 \%$, well above average values for the Aalenian $(-1.54 \%$ ), were recorded during this time interval.

$\delta^{18} \mathrm{O}_{\text {bel }}$ values gradually increased during the Murchisonae Biochron, but an abrupt and well marked negative excursion, reaching $\delta^{18} \mathrm{O}_{\text {bel }}$ values up to $-2.9 \%$, was developed during the Bradfordensis Biochron, coinciding with a negative $\delta^{13} \mathrm{C}_{\mathrm{bel}}$ excursion. Less negative values, averaging $-1.18 \% \delta^{18} \mathrm{O}_{\text {bel }}$ were recorded during the Gigantea and part of the Concavum biochrons (Gigantea-Concavum positive excursion), but a new short-lived negative shift up to $-2.47 \%$ 。 ${ }^{18} \mathrm{O}_{\text {bel }}$ was recorded near the Concavum-Limitatum boundary. After a short rebound, highly negative $\delta^{18} \mathrm{O}_{\text {bel }}$ values were reached abruptly during the late Limitatum and the early Discites biochrons, coinciding with the Aalenian-Bajocian transition, marking the Limitatum-Discites negative excursion. Finally, also negative $\delta^{18} \mathrm{O}_{\text {bel }}$ values $(-2.71 \%$ ) were obtained in belemnites from the Lower Bajocian (Laeviuscula Zone), but these values should be cautioned due to the lower stratigraphical and sampling resolutions in this part of the section.

\subsection{Aalenian $\delta^{18} \mathrm{O}_{\text {bet }}$-based palaeotemperature curve}

Measurements of $\delta^{18} \mathrm{O}$ values performed on diagenetically screened belemnite rostra have been considered by many authors as one of the most reliable tools to be used as a proxy for calculation of seawater palaeotemperatures (Sælen et al., 1996; McArthur et al., 2000; Rosales et al., 2001a,b; Bailey et al., 2003; Jenkyns, 2003; Rosales et al., 2003, 2004; Gómez et al., 2008).

Based on the obtained $\delta^{18} \mathrm{O}_{\text {bel }}$ values, the Aalenian seawater temperatures recorded in the belemnite rostra have been calculated using the equation of Anderson and Arthur (1983): $T\left({ }^{\circ} \mathrm{C}\right)=16.0-4.14$ $\left(\delta_{c}-\delta_{w}\right)+0.13\left(\delta_{c}-\delta_{w}\right)^{2}$, where $\delta_{c}=\delta^{18} \mathrm{O}$ PDB composition of the sample, and $\delta_{w}=\delta^{18} \mathrm{O}$ SMOW composition of ambient seawater. Normal values of $S=34.3 \%$ for the marine salinity (Wright, 1987) and $\delta_{w}$ values of $-1 \%$ for a non-glacial ocean water were assumed.

The resulting palaeotemperature curve is shown in Fig. 5. Average calculated temperature for the studied interval is $18.3{ }^{\circ} \mathrm{C}$, which is compatible with the temperature values measured in current oceans by the National Oceanic and Atmospheric Agency (NOAA, 2007), taking into account that the palaeolatitude calculated for Madrid during the Toarcian was about $35-36^{\circ} \mathrm{N}$ (Osete et al., 2000), around $4-5^{\circ}$ south of its current position, and that the Jurassic climate has been assumed to be warmer than present (Chandler et al., 1992; Bailey et al., 2003; Sellwood and Valdes, 2006).

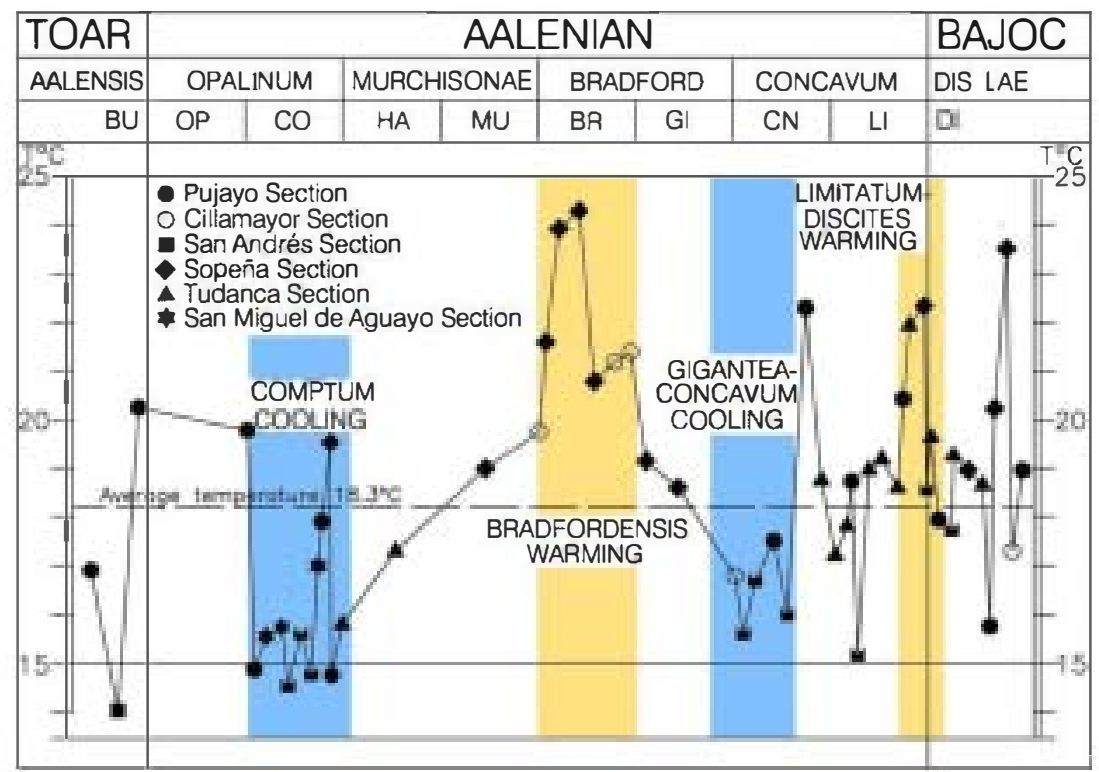

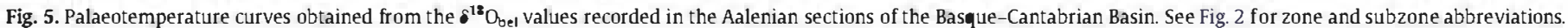




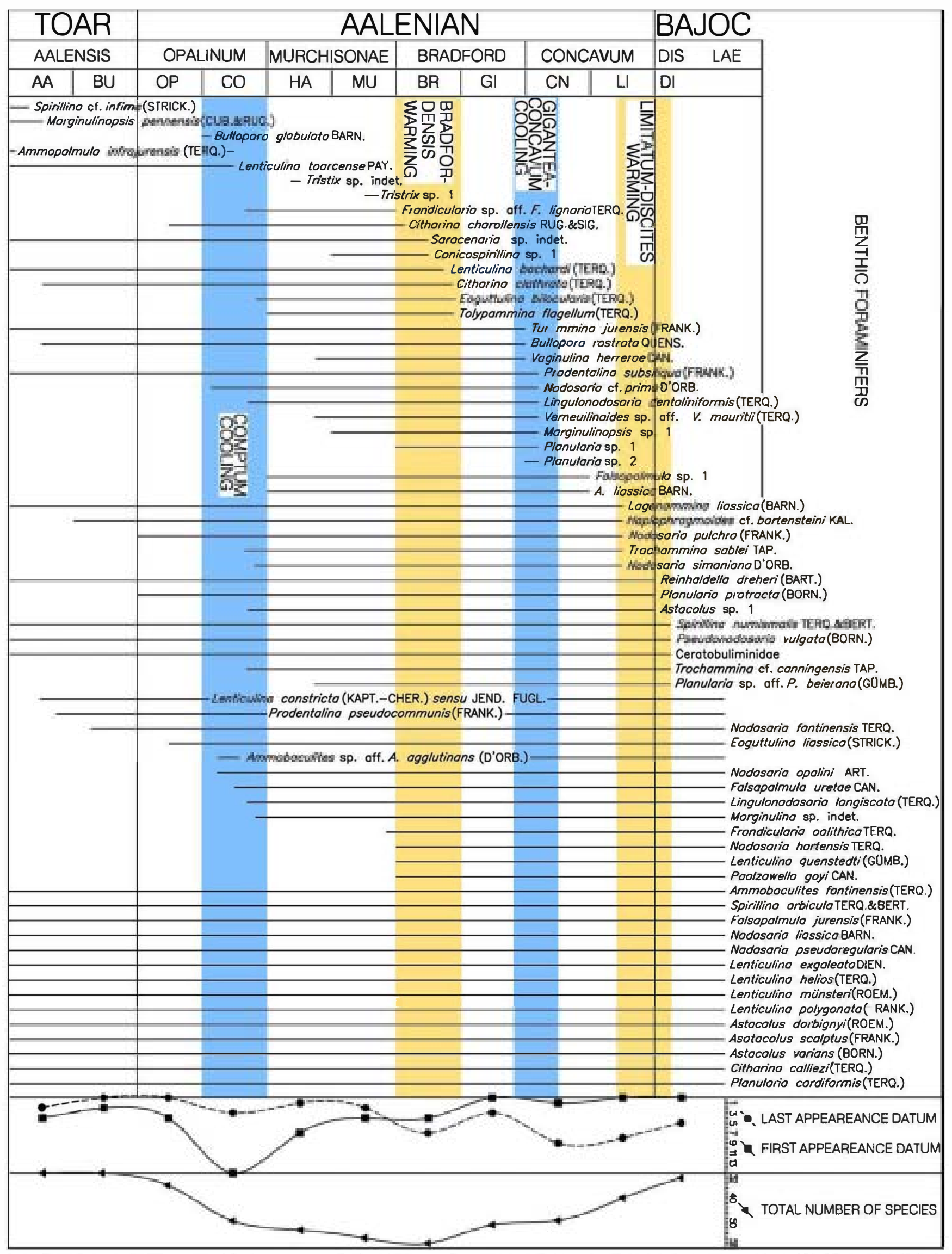

Fig. 6. Stratigraphical distribution of the uppermost Toarcian to lowermost Bajocian benthic foraminifers in the Basque-Cantabrian Basin, modified after Canales (2001), and the intervals of significant changes in seawater temperature. Species are arranged by their last appearance datum (1 AD) and long-ranging species, supposed to be generalist and resistant to environmental changes, are shown in the lower part of the chart. Curves at the bottom of the figure show the recorded variations in the number of FADs and IADs and in the total number of species. See Fig.2 for zone and subzone abbreviations. 
During the Toarcian-Aalenian transition, after an interval of slightly above average temperature, a remarkable decrease occurred during the Comptum Biochron. The calculated average temperature of $15.7{ }^{\circ} \mathrm{C}$ represents a $\Delta T$ of about $-4.3{ }^{\circ} \mathrm{C}$ with respect to the values obtained for the Toarcian-Aalenian transition, marking the Comptum cooling interval. In spite of the presence of an ephemeral warming peak, this interval represents the coldest average temperatures recorded in the Aalenian of the Basque-Cantabrian Basin.

Temperatures increased to closer to average values during the Murchisonae Biochron. The early part (Haugi Biochron) shows temperatures below average, but they pass into temperatures above average at the Murchisonae Biochron. A notable and rapid increase in temperature was recorded during the Bradfordensis warming interval, when average values surpassed $20.6{ }^{\circ} \mathrm{C}$, and a peak value of $24 .{ }^{\circ} \mathrm{C}$ was reached. Total $\Delta T$ between the Comptum thermal low and the Bradfordensis warming is in the order of $5{ }^{\circ} \mathrm{C}$.

A new decrease in temperature took place during the late Gigantea and the early Concavum biochrons. Average seawater temperature marking the Gigantea-Concavum cooling interval was as low as $16.5^{\circ} \mathrm{C}$. An ephemeral thermal peak seems to appear during the late Concavum Biochron, but a more significant warming episode was recorded at the Limitatum Biochron, extending up to the earliest part of the Discites Biochron. During this warming interval, representing a $\Delta T 2.5^{\circ} \mathrm{C}$, temperatures above $20{ }^{\circ} \mathrm{C}$ ( up to $22.3^{\circ} \mathrm{C}$ ) were reached in this part of the basin. The thermal peak recorded at the Laeviuscula Biochron will not be considered, as it is based on just one sample.

\section{Stratigraphical distribution of the Aalenian benthic foraminifers and ammonites}

\subsection{Benthic foraminifers}

Distribution of the benthic foraminifers studied by Canales (2001) in the Aalenian deposits of the Basque-Cantabrian Basin (Fig. 6) records how the species are replaced with time and allows quantification of species appearances and disappearances in each of the distinguished time intervals. Species which range through the entire Aalenian are also represented and included in the counting.

At the lowermost Aalenian (OpalinumSubzone), 4 species had their FAD and no disappearances were found (Fig. 6). However, the diversity of the benthic foraminiferal assemblages considerably increased at the Comptum Subzone, where as much as 14 species were new appearances and only 3 species disappeared. The increase of foraminiferal diversity continued during the Murchisonae Zone. At the Haugi Subzone, 7 species appeared and only 1 species disappeared. At the Murchisonae Subzone the increase of diversity continued but at a more moderated rate. Only 4 new species appeared and only 1 disappeared.

The Bradfordensis Subzone represents a critical interval. From the 58 species recorded, representing the maximum diversity values of the Aalenian, a total of 7 species disappeared and only 4 had their FAD. This marks a first down turn in the diversity of the foraminiferal benthic assemblages. The negative tendency continued at the uppermost Gigantea-lower Concavum subzones, which represents one of the most critical time intervals for the diversity of the Aalenian foraminiferal assemblages in the Basque-Cantabrian Basin. At this period, 10 species disappeared and only 1 ephemeral FAD was recorded. The late Concavum and the early Limitatum time interval does not record major changes in the foraminiferal assemblages. From the 42 accounted species only 2 disappeared, but no new appearances were recorded.

The most important loss in the Aalenian foraminiferal species was reached during the middle Limitatum to the early Discites biochrons. During this interval, 13 species disappeared and no new species appeared, marking one of the most important foraminiferal turnovers of the Aalenian.

\subsection{Ammonoids}

The stratigraphical distribution of the ammonoids collected in the Aalenian successions of the Basque-Cantabrian Basin is summarized in Fig. 7. On the basis of their stratigraphical continuity, the character shown by the different populations and the taphonomical features such as the indications of necroplanktonic drifting processes, three groups of ammonoids have been distinguished. The first group, which includes the informally called "indigenous fauna" (Fig. 7a), corresponds to the last representatives of the subfamily Grammoceratinae (latest Toarcian) and the cosmopolitan family Graphoceratidae (Aalenian), which are present in the NW Europe and in the Tethys provinces. The Graphoceratidae recorded in the Basque-Cantabrian Basin show a continuous replacement of the successive genera and species from the earliest Aalenian to the earliest Bajocian. The assemblages are constituted by shells corresponding to juvenile and adults individuals belonging to female and male forms, indicating that these are local populations. The FADs of several genera and species of this group have been used to establish the biochronostratigraphic scale.

The second group of ammonoids, informally named here the "immigrant fauna" (Fig. 7b) shows a discontinuous and not very longstanding record, but the presence of its constituents has been documented in most sections in equivalent stratigraphic intervals. This group is represented by scarce specimens, generally corresponding to exemplars adults, and its distribution pattern seems to correspond to a model of several unsuccessful attempts by Mediterranean groups to colonize the basin.

The third group, informally called here the "exotic fauna" (Fig. 7c), is composed of ammonoids representative of groups adapted to deep oceanic environments. Their record is restricted to the high-energy tempests of the Murchisonae Zone in the areas surrounding the depocentre. This group is represented by large shells that were transported by currents during the high energy intervals and deposited at the bottom of the shallower platform. They commonly show evidence of necroplanktonic drift, such as encrusting organism colonizing the internal part of the shells.

At the subzone level, significant variations have been recorded at the basin scale in the abundance of specimens of ammonoids (Fig. 7d), in the variations of the frequencies of the different taxonomical groups belonging to the immigrants and the exotic faunas (excluding the Graphoceratidae) (Fig. 7e), in the frequency distribution of the three described groups of faunas (Fig. 7f) and in the distribution of lithofacies and the main sedimentary discontinuities (Fig. 7g). The graphoceratids ("indigenous fauna") are consistently dominant in diversity as well as in abundance during the Aalenian, being virtually exclusively present in some intervals (i.e. Gigantea Subzone). However, from the Concavum Subzone they start to decline and abruptly disappear at the lowermost Bajocian Discites-Laeviuscula transition. The "immigrant fauna" (the genus Vacekia together with hammatoceratids, tmetoceratins and erycitids) represents $10-20 \%$ of the total, but a successive replacement among them seems to occur. During the ToarcianAalenian transition, the Grammoceratinae genus Vacekia appears together with the hammatoceratid Bredyia, which continues alone at the Opalinum Subzone. Abundant specimens of the genus Tmetoceras appear suddenly at the Comptum Subzone, together with the first representatives of the Erycitidae (Spinammatoceras) and Lytoceratina, reaching the maximum of diversity and abundance at the Haugi and Murchisonae subzones. During the GiganteaBradfordensis interval a marked decrease in the abundance and diversity starts. In fact, no specimens belonging to these groups have been recorded at the Gigantea Subzone. An increase of the hammatoceratids occurred at the Concavum Subzone and especially of the erycitids, which become exclusive with the genus Haplopleuroceras at the Limitatum Subzone. 


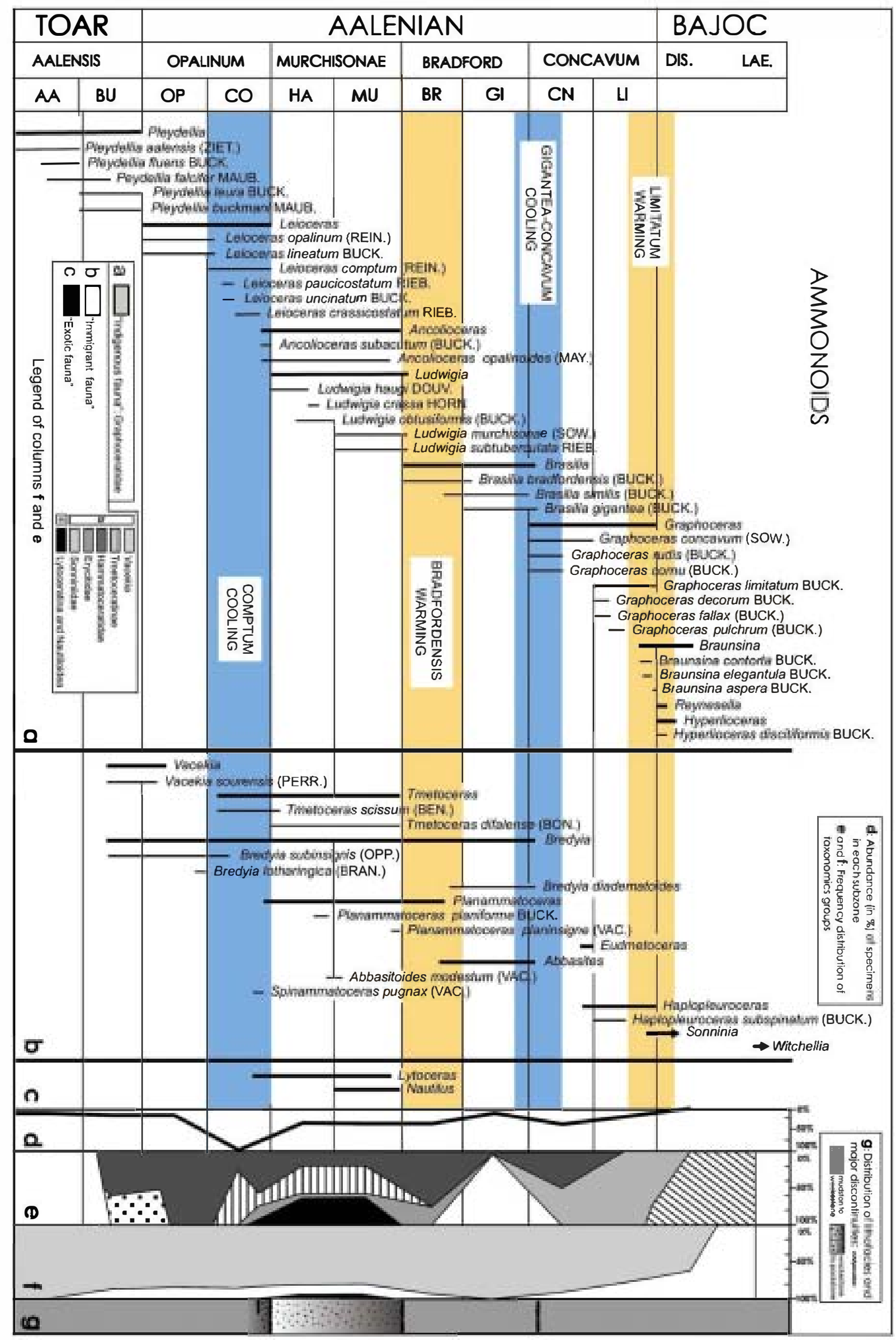


An abrupt increase of the specimen abundance (Fig. 7d) is recorded in the Comptum Subzone, followed by a slow decrease up to the Gigantea Subzone, where the minimum values of the Aalenian are reached. An ephemeral increase is recorded in the Concavum Subzone, but it decreases to minimum values at the lowermost Bajocian.

\section{Discussion}

\subsection{Basin analysis}

Facies and thickness distribution of the Aalenian sediments in the Basque-Cantabrian Basin suggest that, as many other Mesozoic basins located in Central Europe, these sediments were deposited in a nearly symmetrically subsiding sub-basin included in an intraplate shallow platform, developed over continental crust after the Variscan deformation. The tectonic regime was consistent with a moderately extensional post-rift episode; the lack of evidence for fault-controlled basin geometry (Fig. 2a, c) suggests that flexure of a thick continental crust was the main control on basin evolution.

Deposits of the southwestern, more slowly subsiding parts of the basin, contain a number of unconformities generated by the interaction between the sea-level changes and the occasional emersion and erosion of the southwestern border of the near elliptically-shaped basin.

Depositional rates are modest, less than $4 \mathrm{~m} / \mathrm{Ma}$ in the depocentre area, but the basin is open to the east, where no outcrops of the Aalenian deposits are available and the stratigraphical resolution of the oil-wells drilled in the neighbouring areas is uncertain. A migration of the depocentre area is also notable. During the Early and Middle Toarcian the depocentre is located in the San Andres area (Gómez and Goy, 2000), whereas during the Late Toarcian (Mactra Biochron) it migrated about $20 \mathrm{~km}$ north-northeast to the Pujayo area and during the Aalenian it moved south-southeast about $10 \mathrm{~km}$ to the San Miguel de Aguayo area (Fig. 2c).

6.2. Comparison between the Aalenian $\delta^{13} C_{\text {bel }}$ and $\delta^{18} \mathrm{O}_{\text {bel }}$ curves in the Basque-Cantabrian Basin and the records obtained in other areas

Oscillations in the stable isotope values recorded in the belemnite calcite of the Basque-Cantabrian Basin reflect marked changes in the environmental conditions during the Aalenian. Little is known about the geographic extent of the $\delta^{13} \mathrm{C}_{\text {bel }}$ and the $\delta^{18} \mathrm{O}_{\text {bel }}$ excursions reported in this work, as the stable isotope records reported in other areas are scarce, many of them are obtained on bulk carbonates and problems in correlating and accurately dating the sections in other regions remain unresolved. However, there is good parallelism between the $\delta^{13} \mathrm{C}_{\text {bel }}$ curve obtained in northern Spain and the curves obtained by Sandoval et al. (2008) in the Subbetic (southem Spain) and the Umbria-Marche-Sabina (Italy) areas. The Comptum-Haugi positive $\delta^{13} \mathrm{C}_{\mathrm{bel}}$ excursion could correlate with the Lower Aalenian (Comptum Subzone) excursion reported by these authors. The Bradfordensis negative excursion seems to correspond with the Middle Aalenian (Bradfordensis Zone) minimum $\delta^{13} \mathrm{C}_{\mathrm{bulk}}$ also reported by Sandoval et al. (2008). The Gigantea-Concavum $\delta^{13} C_{\text {bel }}$ positive excursion also could be correlated with the Upper Aalenian (Concavum Zone and Subzone) positive ${ }^{13} C_{\text {bulk }}$ peak reported by
Sandoval et al. (2008), and the minimum $\delta^{13} C_{\text {bulk }}$ near the AalenianBajocian boundary reported by these authors could correspond to the Limitatum-Discites $\delta^{13} \mathrm{C}_{\text {bel }}$ negative excursion reported in this work, supporting the idea that these oscillations could have a considerable extent.

Jenkyns et al. (2002) mentioned the presence of a sharp positive ${ }^{13} \mathrm{C}_{\text {bel }}$ peak in the Murchisonae Zone of the Bearreraig section in the Isle of Sky (UK) and a slight increase in the $\delta^{13} \mathrm{C}$ values in bulk carbonates of the Murchisonae Zone was also reported by Duarte (1998) in some sections of the Lusitanian Basin (Portugal) (Fig. 1b). These excursions could be partly correlated with the $\delta^{13} C_{\text {bel }}$ excursion found in belemnites of the uppermost Opalinum-lowermost Murchisonae zones of the Basque-Cantabrian Basin (Fig. 4). The c. 1.5\% negative excursion recorded in the deposits of the uppermost Aalenian (Limitatum Subzone) and the lowermost Bajocian (Discites Zone) can also be correlated with the $0.8 \%$ negative excursion found by O'Dogherty et al. (2006) and Sandoval et al. (2008) in the bulk carbonates of the Subbetic sections of southern Spain (Fig. 1b). Correlation with the $\delta^{13} \mathrm{C}$ curves obtained in central Italy from bulk carbonates (Bartolini et al., 1996, 1999; Morettini et al., 2002) is uncertain in the Terminilletto section due to the lack of a detailed biostratigraphy. However, correlation with the ${ }^{13} \mathrm{C}_{\text {bulk }}$ obtained in the Presale section shows a general good correlation with the curve obtained in this work.

The Aalenian $\delta^{18} \mathrm{O}_{\text {bel }}$ and calculated palaeotemperature curves show remarkable climate oscillations, but unfortunately no correlation with other curves can be performed, as no reliable Aalenian

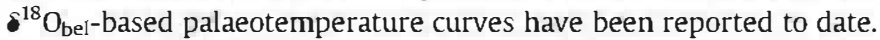
The about $20{ }^{\circ} \mathrm{C}$ palaeotemperatures at the Toarcian-Aalenian boundary calculated in northern Spain (Gómez et al., 2008), were quite similar to the temperatures recorded in the studied area. These temperatures continued up to the earliest Comptum Biochron, on which a significant drop in temperatures to average values of $15.7{ }^{\circ} \mathrm{C}$ is recorded. The alternation of warming and cooling intervals during the Aalenian is well represented by the instability in the environmental conditions reflected by the biota as will be discussed below.

\subsection{Possible causes of the Aalenian climate changes}

Mechanisms causing the changes in seawater temperature recorded in the Basque-Cantabrian Basin during the Aalenian are uncertain and further research on this subject, which is beyond the scope of this work, should be performed. First, it is unknown if the inferred climate changes are of global or of local extent. The lack of studies on this subject does not allow resolution of this problem. As a preliminary hypothesis, if the cooling intervals are not of global extent and consequently they are not due to global causes, they could be explained by the action of enhanced southwards currents following the predominant wind and currents direction, as modelled by Bjerrum et al. (2001) for the transcontinental Laurasian Seaway. This would favour the arrival of artic waters to the lower latitudes at which Iberia was located.

Interestingly, the recorded warming episodes coincide with significant, at least $-0.8 \%$ to $-1 \%$ negative $\delta^{13} \mathrm{C}$ excursions, and can be compared with several hypotheses proposed regarding other warming episodes associated with negative carbon isotope excursions

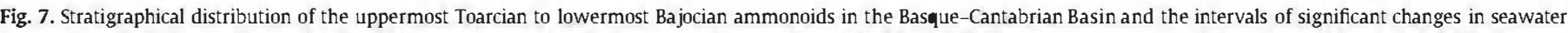

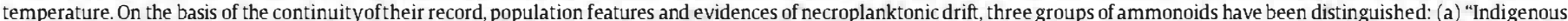

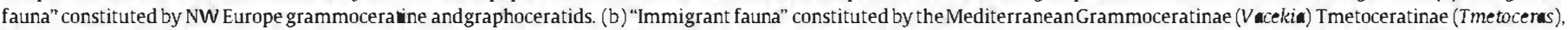

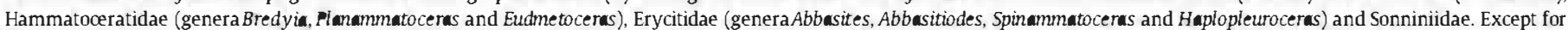

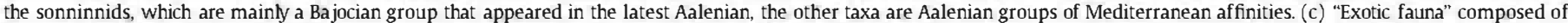

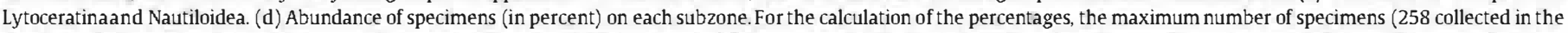

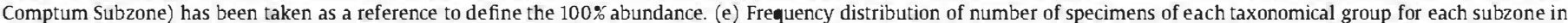

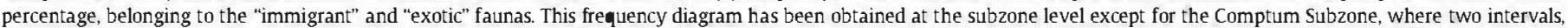

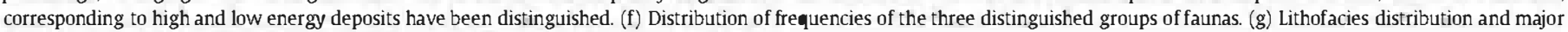
stratigraphical discontinuities. Mudst.-mudstone, wackst.-wackestone, packst.-packstone.
} 
(i.e. the Early Toarcian warming and the Paleocene-Eocene Thermal Maximum, Cohen et al., 2007). One of the most popular hypothesis is the release of methane to the ocean-atmosphere system, either due to dissociation of methane hydrate accumulated in marine continental margin sediments (Hesselbo et al., 2000) or to thermogenic methane released during the massive intrusion of igneous rocks into organicrich sediments (Svensen et al., 2007). The second hypothesis is very improbable in this case, as no large igneous provinces of Aalenian age have been reported to date. One of the main unknowns for the evaluation of the first hypothesis is the uncertainty in the amount of methane hydrate stored on the seafloor during the Aalenian and, consequently, if the amount of released methane was sufficient to produce the greenhouse effect that would have raised the seawater temperature in the order of $4-5{ }^{\circ} \mathrm{C}$. Estimates for the sensitivity of the climate system indicated that $\mathrm{CO}_{2}$ mass involving around $4-5 \times 10^{3} \mathrm{Gt}$ of carbon would have been required to produce this increase in seawater temperature (Zachos et al., 2003; Tripati and Elderfield, 2005; Cohen et al., 2007). However, the resultant carbon negative excursion produced by the $\mathrm{CO}_{2}$ derived from methane would probably be greater than the values found in the Aalenian (Cohen et al., 2007).

In addition, the release of such a massive amount of $\mathrm{CH}_{4}$ poses serious problems about the storage capacity of the Aalenian oceans. Estimated reserves of marine methane hydrate in the present-day oceans are uncertain, between 500 and $2500 \mathrm{Gt}$ of methane carbon (Milkov, 2004). Even in the highest estimate, these figures would not be sufficient for the calculated Aalenian temperature rises. Nevertheless, some authors have suggested that some cooling intervals may have allowed greater gas hydrate formation on continental margins (Beerling and Brental, 2007), which in our case would potentially increase the storage of methane during the Comptum and the Gigantea-Concavum cooling intervals, and this methane could probably be released during the Bradfordensis and Limitatum-Discites warming intervals. Nevertheless, within the current limits of knowledge, the role of gas hydrate in global change seems to be overestimated (Milkov, 2004) and considerable uncertainties surrounding the possible causes of these climate oscillations are still present.

\subsection{The Aalenian biotic changes linked to the palaeotemperature oscillations}

A close relationship between the changes in seawater temperature and the biotic changes recorded in the foraminiferal assemblages can be observed in Fig. 6. The number of FADs and I.ADs of benthic foraminiferal species present on each considered stratigraphic interval reveals important variations in the composition of the fossil assemblages. The disappearances and new appearances at the different stratigraphic intervals can be correlated with the climate changes obtained from the isotopic study. As nektonic organisms, the relationship between the distribution and the abundance of ammonoids and the changes in seawater temperature are less manifest, as expected, but still some remarkable links have been observed.

During the latest Toarcian and the earliest Aalenian (Opalinum Biochron), temperatures were around Aalenian average $\left(18.3^{\circ} \mathrm{C}\right)$ and the foraminiferal assemblages were mainly constituted by typically Toarcian taxa, common in other NW European platforms. Ammonoid abundance and diversity were generally low.

\subsubsection{The Comptum cooling}

At the Comptum Biochron, three important phenomenons are coincident: 1st) A well marked cooling event, on which seawater temperature was lowered to an average of $15.7{ }^{\circ} \mathrm{C}$ (Fig. 5), 2nd) a strong increase in the diversity of the foraminiferal assemblages (Fig. 6) and 3rd) a notable increase of the abundance and the diversity of ammonoids (Fig. 7d). Coinciding with this climate change towards cooler conditions, 14 foraminiferal species had their FAD and only 3 disappeared. This noteworthy incorporation of new taxa can be interpreted as the result of the immigration of species that thrived in other platforms located to the north, in the Laurasian Seaway, where seawater temperatures were normally colder than the temperatures of the platforms of Iberia. This suggestion is supported by the presence of dominant southwards winds and currents along the Laurasian Seaway (Bjerrum et al., 2001), which strongly conditioned the southwards migration of some benthic organisms, corroborated by the distribution of the ostracods during most of the Toarcian (Arias, 2006, 2007).

A review of the published stratigraphical distribution of many of the foraminiferal species that appeared in the Basque-Cantabrian Basin during the Comptum cooling supports the idea that this platform was colonized during this interval by species that have been found in older deposits of the Northern Europe Boreal province. As an example, Nodosaria simoniana has been identified in the Lower Jurassic deposits of France (Terquem, 1858; Payard, 1947) and Germany (Franke, 1936; Riegraf, 1985). Also Frondicularia lignaria has been reported in the Lower Jurassic deposits of France (Terquem, 1866), Germany (Franke, 1936; Karampelas, 1978) and in the UK (Barnard, 1950a). This notable increase in the foraminiferal diversity at the Comptum Subzone has also been observed in other Aalenian sections of Iberia. In the Murtinheira section (Lusitanian Basin, Portugal) a $25 \%$ of FADs have been recorded during this time interval (Canales and Henriques, 2008). In the Iberian Range (central Spain, Fig. 1b) a $18 \%$ of FADs were recorded at this biochron in the Fuentelsaz section, the Aalenian GSSP, (Goy et al., 1994; Canales, 2001) and in the Moyuela section, 3 new FADs were reported by Canales and Herrero (2000).

The increase in abundance of ammonoids in the BasqueCantabrian Basin during the Comptum cooling is also remarkable. The number of specimens recorded in this interval is four times higher than the next interval of maximum abundance, which coincides with other cooling interval (the Gigantea-Concavum cooling). Also brachiopods record a notable diversity increase in the Iberian Range at the Comptum Subzone, where the number of species doubles with respect to previous intervals in some sections, such as Fuentelsaz (García Joral and Goy, 1994; Goy et al., 1994) or increases $30 \%$ in other sections (García-Joral et al., 1990).

The Comptum Biochron coincided with a $\delta^{13} C_{\text {bel }}$ positive excursion which may reflect rapid burial of large amounts of organic carbon rich in ${ }^{12} \mathrm{C}$ that led to enrichment in ${ }^{13} \mathrm{C}$ of the sediments (Jenkyns and Clayton, 1997; Schouten et al., 2000) probably coupled with changes in biological productivity (Holser, 1997). In the case of the BasqueCantabrian Basin, the ${ }^{13} \mathrm{C}_{\text {bel }}$ positive excursion coincided with the highest amount of specimens of ammonites recorded during the Aalenian, which could be linked to an increase of nutrients supplied by the southwards currents circulating along the Laurasian Seaway.

\subsubsection{The Murchisonae temperature rebound}

The Murchisonae Biochron represents a progressive increase of temperature by $4.8{ }^{\circ} \mathrm{C}$. However, response of the foraminiferal assemblages to this increase should be subdivided into two intervals that roughly correspond with the subzonal divisions. In the first interval (Haugi Biochron), temperatures were still below average and immigrants were mainly coming from the northern cooler areas. As a result, 7 FADs and only 1 I.ADwere recorded (Fig. 6). These immigrants include Planularia beierana, identified in the Lower Jurassic deposits of Germany (Bartenstein and Brand, 1937) and Tolypammina flagellum reported in the Lower Jurassic deposits of the UK (Macfadyen, 1941; Barnard, 1950b, 1958), France (Brouwer, 1969) and Germany (Riegraf, 1985). At the beginning of the second interval (Murchisonae Biochron), the temperature rose to values above average and the number of FADs was reduced to 4 and 2 species disappeared. Most of the taxa that appeared during the Murchisonae Biochronwere adapted to warm seawaters, as supported by the fact that some of these taxa (Vaginulina herrerae and Marginulinopsis sp. 1) thrived during the 
Bradfordensis warming but disappeared later on during the GiganteaConcavum cooling interval. A notable decrease in the diversity of the brachiopods was reported in the Iberian Range at the Murchisonae Zone by Garcia-Joral et al. (1990). From the 9 genera recognized in the Comptum Subzone only 2 genera persisted.

Among the ammonoids, six taxonomical groups above the subfamily level were recorded at the uppermost Comptum Subzone and the Murchisonae Zone marking a notable increase in the diversity (Fig. 7e). The presence of ammonoids and Nautiloidea typical of the Mediterranean province contained in the tempestitic deposits of the Murchisonae Zone, arrived to the Basque-Cantabrian Basin mainly through necroplanktonic drift, giving rise to the recorded increase in the diversity and supporting the good communication between the Tethys and northern Iberia.

\subsubsection{The Bradfordensis warming}

The rapid temperature increase represented by the Bradfordensis warming interval (peak values up to $24.3^{\circ} \mathrm{C}$ ) marks the change in tendency from the increase of foraminiferal diversity to the beginning of the progressive diversity losses in successive intervals. 7 species disappeared and only 4 species had their FAD (Fig. 6). Most of the disappeared species, such as Frondicularia aff. lignaria, Conicospirillina sp. 1, Eoguttulina bilocularis and Tolypammina flagellum, seem to be immigrants from NW Europe that had their FAD in the BasqueCantabrian Basin coinciding with the Comptum cooling interval or the early Haugi interval, with temperatures below average, that were not adapted to the remarkable rise in seawater temperatures recorded during the Bradfordensis Biochron.

The benthic species could not migrate back again towards the northern cooler latitudes due to the predominant southward currents in the Laurasian Seaway (Bjerrum et al., 2001) that dispersed the embryos and gametes generated by the benthic foraminifers to the south. The link between the distribution of the genus Spirillina and the seawater temperature changes is remarkable. The relative abundance of representatives of this genus increases at the warming intervals, reaching the maximum relative abundance during the Bradfordensis warming. This bio-event has also been recorded in the Lusitanian Basin of Portugal as an increase in the relative abundances of this genus (Canales and Henriques, 2008), whereas during the cooling intervals the number of specimens of this genus notably decreases. The Bradfordensis warming coincides with the onset of a notable crisis in the abundance of ammonoids, which continue to decrease up to the Gigantea Biochron, where the minimum values of Aalenian abundance and diversity were reached.

\subsubsection{The Gigantea-Concavum cooling}

During the Gigantea Biochron, seawater temperature progressively decreased to about average values and consequently changes in the benthic foraminiferal assemblages were stabilized. However, coinciding with the Gigantea-Concavum cooling interval, a severe crisis was recorded. Some $19 \%$ of the foraminiferal species disappeared while the new appearances only represented a $2 \%$. Several species that colonized the Basque-Cantabrian Basin during the rise in temperature recorded at the late Murchisone Biochron and that thrived during the Bradfordensis warming interval, disappeared during the GiganteaConcavum cooling. Examples include Vaginulina herrerae, Verneuilinoides aff. mauritii, Marginulinopsis sp. 1 and Planularia sp. 1 . The response of ammonoids to this new cooling event is a new increase in the abundance (Fig. 7d) although it is not as marked as the increase recorded at the Comptum cooling.

\subsubsection{The Limitatum-Discites warming}

A relative stabilization in the number of foraminiferal species occurred during the late Concavum and the early Limitatum biochrons, where $\mathrm{a} \sim 5 \%$ of the species were lost and not new appearances were recorded. However, the late Limitatum-early Discites biochrons again represent a notable warming interval in which an average $\Delta T$ of $2.8^{\circ} \mathrm{C}$ was recorded. Biotic response to this new palaeonvironmental change is remarkable. As much as one third of the benthic foraminiferal species disappeared and no new appearances were found, marking one of the most important biotic changes of the Aalenian. Some species that arrived to the Basque-Cantabrian Basin during the Comptum cooling interval and that survived the previous climate changes disappeared during this warming interval (including Trochammina sablei, $T$. cf. canningensis, Nodosaria cf. simoniana, Astacolus sp. 1 and Planularia aff. beierana).

Although it has not been previously linked to an abrupt increase in seawater temperature, the notable biotic changes recorded during the Limitatum-Discites biochron has been reported from other parts of the world. In the UK, Morris (1982) and Morris and Coleman (1989) recognized a major turnover in the foraminiferal assemblages in the upper part of the Concavum Zone and the lower part of the Discites Zone. In the Aalenian of NW Caucasus, Ruban and Tyszka (2005) documented a high diversity of the foraminiferal assemblages in the lower half of the Aalenian, but a drastic fall in the diversity in the upper half of the Aalenian, which these authors link to a regional cooling in water masses. The loss in the diversity of the benthic foraminifers at the Limitatum Subzone has also been reported in the Lusitanian Basin of Portugal (Canales and Henriques, 2007, 2008) where a massive amount (72\%) of the foraminiferal species had their LAD. In the Moyuela section (Iberian Range), there is a stratigraphic gap affecting most of the Bradfordensis Zone and all of the Concavum Zone. Nevertheless, from 25 species recorded in the Murchisonae Zone only 9 species of foraminifers survived in the Discites Zone, indicating a major crisis at that time (Canales and Herrero, 2000). This crisis is also reflected in the loss of diversity of brachiopods at the Iberian Range (Garcia Joral, 2005) and at the Lusitanian Basin at the Limitatum Subzone, with an increase starting at the middle Discites Zone (Andrade, 2006).

Ammonoids in the Basque-Cantabrian Basin during the Limitatum-Discites warming show a decrease in abundance, preceding a drastic decrease in the species diversity which coincides with the disappearance of the graphoceratids, hammatoceratids, and erycitids of the basin. The latest Aalenian to earliest Bajocian biotic change coincides with one of the most important ammonite turnover events recorded in the Subbetic area of southern Spain (Fig. 1b), reported by Sandoval et al. (2001) and O'Dogherty et al. (2006). During this crisis in the Subbetic Domain five families or subfamilies (Graphoceratidae, Grammoceratinae, Tmetoceratinae, Hammatoceratidae and Erycitidae), comprising $100 \%$ of the Mediterranean Ammonitina went extinct, and five new families (Haploceratidae, Strigocetatidae, Sonniniidae, Otoitidae and Stephanoceratidae) originated before the Laeviuscula Biochron. The extinction rate was high ( $70 \%$ of the genera) and largely exceeded new appearances, marking one of the most important Middle Jurassic crises of ammonoids.

\section{Conclusions}

The outstanding correlation between climate and biotic changes observed in the Aalenian sections of Northern Spain provides a good example of the strong coupling between the biotic turnover and the temperature variations, as some authors have pointed out (i.e. Crowley and Norton, 1988; Barnosky et al., 2004; Gómez et al., 2008; Mayhew et al., 2008). Climate changes, together with the scenario provided by the palaeoceanographic features, conditioned the migration and new appearances of species in a given area or the disappearance of a part of the populations that inhabited these areas.

Based on the obtained $\delta^{18} \mathrm{O}_{\text {bel }}$ values, the Aalenian calculated seawater temperatures show a remarkable decrease $\left(\Delta T \sim-4.3{ }^{\circ} \mathrm{C}\right)$ during the Comptum cooling interval, which coincided with a strong increase in the diversity of the foraminiferal assemblages and a notable increase in the abundance and the diversity of ammonoids. 
The Murchisonae Biochron represents a progressive increase of temperature $\left(\Delta T 4.8{ }^{\circ} \mathrm{C}\right)$. During the Haugi Biochron temperatures were still below the Aalenian average temperature $\left(18.3^{\circ} \mathrm{C}\right)$ and foraminiferal immigrants were mainly coming from the northern cooler areas. As a result, 7 FADs and only 1 I.AD were recorded. Among the ammonoids, six taxonomical groups above the subfamily level were recorded during the latest Comptum and the Murchisonae biochrons, marking a notable increase in the diversity.

A rapid temperature increase was recorded during the Bradfordensis warming interval, when average values surpassed $20.6^{\circ} \mathrm{C}$. This marked the beginning of the progressive diversity losses in successive intervals. Twelve percent of the foraminiferal species disappeared and only 7\% of the species had their FAD. Most of the disappeared species seem to be immigrants from NW Europe that had their FAD in the Basque-Cantabrian Basin coinciding with the Comptum cooling interval or the early Haugi interval, which were not adapted to the significant rise in seawater temperature. The benthic species could not migrate back again towards the northern cooler latitudes due to the predominant southward currents in the Laurasian Seaway. The Bradfordensis warming also coincides with the onset of a notable crisis in the abundance of ammonoids, which continued to decrease up to the Gigantea Biochron, where the minimum values of Aalenian abundance and diversity were reached.

A new decrease in temperature took place during the GiganteaConcavum cooling interval when average seawater temperature was $16.5^{\circ} \mathrm{C}$. Coinciding with this cooling interval, a severe biotic change was recorded. Some 19\% of the foraminiferal species disappeared while only a $2 \%$ were new appearances. Several species that colonized the Basque-Cantabrian Basin during the late Murchisonae Biochron rise in temperature and that thrived during the Bradfordensis warming interval, disappeared during this cooling interval. On the contrary, as in previous cooling intervals, ammonoids recorded a new increase in the abundance.

A new significant warming $\left(\Delta T 2.8^{\circ} \mathrm{C}\right)$ episode was recorded the Limitatum Biochron, extending up to the earliest part of the Discites Biochron. Biotic response to this temperature change is remarkable. Thirty percent of the benthic foraminiferal species disappeared and no new appearances were found. Species that arrived to the BasqueCantabrian Basin during the Comptum cooling interval and that survived the previous climate changes disappeared during this warming interval. Ammonoids show a decrease in abundance, preceding a drastic decrease in diversity which coincides with the disappearance of the graphoceratids, hammatoceratids, and erycitids of the basin. The latest Aalenian to earliest Bajocian biotic change coincides with one of the most important ammonite turnover events recorded in the Subbetic area of southern Spain, reported by Sandoval et al. (2001) and O'Dogherty et al. (2006).

The succession of remarkable biotic changes linked to seawater temperature variations recorded during the early Middle Jurassic in the Basque-Cantabrian Basin, opens the possibility that these significant climatic changes and faunal turnovers were of global extent.

\section{Acknowledgements}

We gratefully acknowledge Dr. F. Surlyk, Dr. J. Sandoval and an anonymous reviewer for valuable comments and constructive reviews. This research work was financed by projects CGL 200504574/BTE, CGL 2008-03112 and CGL 2008-01273 of the Spanish Ministerio de Educación y Ciencia, and projects CCG07-UCM/AMB2478 and CCG07-UCM/AMB-2132.

\section{Appendix A. Supplementary data}

Supplementary data associated with this article can be found, in the online version, at doi:10.1016/j.palaeo.2009.01.009.

\section{References}

Alonso, J.L., Pulgar, J.A., 2004. Estructura alpina de la Cordillera Cantábrica: generalidades. In: Vera, J.A. (Ed.), Geología de España. SGE-IGME, Madrid, pp. 332-334.

Anderson, T.F., Arthur, M.A., 1983. Stable isotopes of oxygen and carbon and their application to sedimentologic and paleoenvironmental problems. In: Arthur, M.A (Ed.), Stable isotopes in sedimentarygeology. SEPM Short Course 10, pp. 1-1-1-151.

Andrade, B., 2006. Ios braquiópodos del tránsito Jurásico Inferior-Jurásico Medio de la Cuenca Lusitánica (Portugal). Col. Paleontol. 56, 5-194.

Arias, C., 2006. Northern and Southern Hemisphere ostracod palaeobiogeography during the Early Jurassic: possible migration routes. Palaeogeogr. Palaeoclimatol. Palaeoecol 233, 63-95.

Arias, C, 2007. Pliensbachian-Toarcian ostracod biogeography in NW Europe: evidence for water mass structure evolution. Palaeogeogr. Palaeoclimatol. Palaeoecol. 251 398-421.

Aırell, M., Robles, S., Bádenas, B., Rosales, I., Quesada, S., Meléndez, G., García-Ramos, J.C. 2003. Transgressive-regressive cycles and Jurassic palaeogeography of northeast Iberia Sed. Geol. 162, 239-271.

Bailey, T.R., Rosenthal, Y., McArthur, J.M., van de Schootbrugge, B., Thirlwall, M.F., 2003 Paleoceanographic changes of the Late Pliensbachian-Early Toarcian interval: a possible link to the genesis of an Oceanic Anoxic Event. Earth Planet. Sci. Lett. 212, 307-320.

Barnard, T., 1950a. Foraminifera from the Upper Lias of Byfield, Northamptonshire. Q.J Geol. Soc. Iond. 106, 1-36.

Barnard, T., 1950b. Foraminifera from the Lower Lias of the Dorset Coast. Q. J. Geol. Soc. Iond. 105, 347-391.

Barnard, T., 1958. Some Mesozoic adherent foraminifera. Palaeontology 1, 116-124.

Barnosky, A.D., Hadly, E.A., Bell, C.J., 2004. Mammalian response to global warming on varied temporal scales. J. Mammal. 84, 354-368.

Bartenstein, H., Brand, E., 1937. Milro-paläontologische Untersuchungen zur Stratigraphie des nordwest-Deutschen Lias und Doggers. Abh. Senckenb. Naturforsch. Ges. 439, 1-224.

Bartolini, A., Baumgartner, P.O., Hunziguer, J., 1996. Middle and Upper Jurassic carbon stable-isotope stratigraphy and radiolarite sedimentation of the Umbria-Marche Basin (Central Italy). Eclogae Geol. Helv. 98, 811-844.

Bartolini, A., Baumgartner, P.O, Guex, J., 1999. Middle and Late Jurassic radiolarian palaeoecology versus carbon-isotope stratigraphy. Palaeogeogr. Palaeoclimatol. Palaeoecol. 145, 43-60.

Beerling, D.J., Brental, S.J., 2007. Numerical evaluation of mechanisms driving Early Jurassic changes in global carbon cycling. Geology $35,247-250$

Bjerrum, C.J., Surlyk, F., Callomon, J.H., Slingerland, R.L., 2001. Numerical paleoceanographic study of the Early Jurassic Transcontinental Laurasian Seaway. Paleoceanography $16,390-404$.

Brouwer, J., 1969. Foraminiferal assemblages from the Lias of North-Western Europe Ver. K. Ned. Akad. Wet., Afd. Naturk. 25, 1-48.

Canales, M.L., 1992. "Lagenina" (Foraminiferida) del Aaleniense en el Sector Suroccidental de la Cuenca Vasco-Cantábrica. Col. Paleontol. 45, 43-81.

Canales, M.L., 2001. Los foraminíferos del Aaleniense (Jurásico Medio) en la Cuenca Vasco-Cantábrica (N de España). Rev. Esp. Micropaleontol. 33, 253-438.

Canales, M.L., Henriques, M.H., 2007. Análisis cuantitativo de los foraminíferos del Aaleniense (Jurásico Medio) de la sección de Murtinheira (Cabo Mondego, $W$ de Portugal). Consideraciones paleoecológicas. Paleontologia: Cenários de Vida Interciéncia Ltda, Rio de Janeiro, pp. 383-393.

Canales, M.L., Henriques, M.H., 2008. Foraminifera from the Aalenian and the Bajocian GSSP (Middle Jurassic) of Murtinheira section (Cabo Mondego, West Portugal): biostratigraphy and paleoenvironmental implications. Marine Micropaleontology 67, 155-179.

Canales, M.L., Herrero, C., 2000. Asociaciones de foraminíferos del Toarciense superior y Aaleniense en la sección de Moyuela (Zaragoza, España). Rev. Esp. Micropaleontol. 32, 301-317

Canales, M.L., Ureta, S., 1997. Asociaciones de ammonoideos y foraminíferos del Aaleniense en la sección de Castillo Pedroso (Cuenca Vasco-Cantábrica, España). Cah. Univ. Catho. Lyon 10, 19-33.

Canales, M.L., Goy, A., Herrero, C, Ureta, S., 1993. Foraminíferos del Aaleniense en el sector suroccidental de la Cuenca Vasco-Cantábrica. Treb. Mus. Geol. Barc. 3, 19-40.

Chandler, M.A., Rind, D., Ruedy, R., 1992. Pangaean climate during the Early Jurassic: GCM simulations and the sedimentary record of paleoclimate. Geol. Soc. Am. Bull. 104, 543-559.

Cohen, A.S., Coe, A.L., Kemp, D.B., 2007. The Late Paleocene-Early Eocene and Toarcian (Early Jurassic) carbon isotope excursions: a comparison of their time scales, associated environmentalchanges, causes and consequences. J. Geol. Soc. Lond. 146 1093-1108.

Crowley, T.J., Norton, G.R., 1988. Abrupt climate change and extinction events in earth history. Science 240, 996-1002.

Dahm, H., 1965. Stratigraphie und Paläogeographie im Kantabrischen Jura (Spanien) Beih. Geol. Jb. 44, 13-54

Duarte, L.V., 1998. Clay minerals and geochemical evolution in the Toarcian-Lower Aalenian of the Lusitanian Basin (Portugal). Cuad. Geol. Ibérica 24, 69-98.

Fernández-Iópez, S., Goy, A., Ureta, S., 1988. El Toarciense superior, Aaleniense y Bajociense en Camino (Santander). Precisiones bioestratigráficas. III Col. Estratigrafía y Paleogeografía del Jurásico de España. Libro Guía de Excursiones. Ciencias de la Tierra. Geología 11, 47-62.

Franke,A., 1936. Die Foraminiferen des deutschen Lias. Abh. Preuss. Geol. Land., N.F.169, $1-138$.

García-Frank, A., Ureta, S., Mas, R., 2008. Aalenian pulses of tectonic activity in the Iberian Basin, Spain. Sed. Geol. 209, 15-35. 
García Joral, F., 2005. Sphueroidothyris uretae sp. nov. (Brachiopoda, Terebratulida) de Aaleniense superior (Jurásico) del Sector Septentrional de la Cordillera Ibérica (España). Col. Paleontol 55, 163-174

García Joral, F., Goy, A., 1994. The associations of Brachiopods from the Toarcian-Aalenian transition in the Fuentelsaz secrion (Iberian Range, Spain). Geobios M.S. 17, 223-228.

García-Joral, F., Goy, A., Ureta, M.S., 1990. Las sucesiones de braquiópodos en el tránsito Lías-Dogger en la Cordillera Ibérica. Cuad. Geol Ibérica 14, 55-65.

Golonka, J., 2007. Late Triassic and Early Jurassic palaeogeography of the World Palaeogeogr. Palaeoclimatol Palaeoecol 244, 297-307.

Gómez, J.J., Goy, A., 2000. Definition and Organization of Limestone-Marls Cycles in the Toarcian of the Northern and East-Central part of the Iberian Subplate (Spain) GeoRes. Forum 6, 301-310.

Gómez, J.J., Goy, A., Canales, M.L., 2008. Seawater temperature and carbon isotope variations in belemnites linked to mass extinction during the Toarcian (Early Jurassic) in Central and Northern Spain. Comparison with other European sections. Palaeogeogr. PalaeoclimatoL Palaeoecol 258, 28-58.

Goy, A., Ureta, S., 1981. Bioestratigrafía del Aaleniense en Préjano-Muro de Aguas Logroño). Cuad. Geol Univ. Granada 10, 107-119.

Goy, A., Ureta, S., 1991. L'Aalénien dans le Bassin Basque-Cantabrique (Espagne).3rd Int Symp. on Jurassic Stratigraphy. Poitiers, France, p. 58.

Goy, A., Ureta, S., 1994. Bioestratigrafia del Aaleniense en el sector occidental de la Cuenca Vasco-Cantábrica (España). Com. X Jornadas de Paleontología. Madrid, Spain, pp. 102-105

Goy, A., Ureta, S., Arias, C., Canales, M.L., García Joral, F., Herrero, C, Martínez, G., Perilli, N., 1994. The Fuentelsaz section (Iberian range, Spain), a possible Stratotype for the base of the Aalenian Stage. Misc. Serv. Geol Naz. 5, 1-31.

Gräfe, K.U., 2005. Benthic foraminifers and palaeoenvironment in the Lower and Middle Jurassic of Western Basque-Cantabrian Basin (Northern Spain). J. Iber. GeoL 31 $217-233$

Hesselbo, S.P., Gröcke, D.R., Jenkyns, H.C., Bjerrum, C. J., Farrimond, P., Morgans Bell, H.S. Green, O.R., 2000. Massive dissociation of gas hydrate during a Jurassic oceani anoxic event. Nature 406, 392-395

Holser, W.T., 1997. Geochemical events documented in inorganic carbon isotopes. Palaeogeogr. Palaeoclimatol Palaeoecol 132, 173-182.

Jenkyns, H.C., 2003. Evidence for rapid climate change in the Mesozoic-Palaeogene greenhouse world. Phil Trans. R. Soc. Lond. A361, 1885-1916.

Jenkyns, H.C., Clayton, C.J., 1997. Lower Jurassic epicontinental carbonates and mudstones from England and Wales: chemostratigraphic signals and the early Toarcian anoxic event. Sedimentology 44,687-706.

Jenkyns, H.C. Jones, C.E., Gröcke, D.R., Hesselbo, S.P., Parkinson, D.N., 2002 Chemostratigraphy of the Jurassic System: application, limitations and implications for palaeoceanography. J. GeoL Soc. Lond. 159, 351-378.

Karampelas, G., 1978. Foraminiferen eines vollständigen Liasprofils aus der Langebrücker Senke (Nordbaden). Jahr. GeoL Land. Baden-Württemberg 20, 43-66.

Linares, A., Sandoval, J., 1986. Malladaites nov. gen. et Spinammatoceras (Hammatoceratidae, Ammonitina) de I'Aalénien de la Zone Subbétique, Sud de I'Espagne. Geobios 19, 207-224.

Linares, A., Sandoval, J., 1996. The genus Haplopleuroceras (Erycitidae, Ammonitina) in the Betic Cordillera, Southern Spain. Geobios 29, 287-305.

Loeblich, A.R., Tappan, H., 1988. Foraminiferal Genera and Their Classification. Van Nostrand Reinhold Company, New York.

Macfadyen, W.A., 1941. Foraminifera from the Green Ammonite Beds, Lower Lias, of Dorset. Phil Trans. R Soc. Ind., Ser. B 231, 1-73.

Martínez, G., 1992. Hamatoceratinae (Ammonitina) del Toarciense superior y Aaleniense en la Cordillera Ibérica. Colección Tesis Doctorales, Ed. Universidad Complutense de Madrid, 374/92. 311p

Mayhew, P.J., Jenkins, G.B., Benton, T.G, 2008. A long-term association between global temperature and biodiversity, origination and extinction in the fossil record. Proc. Roy. Soc. B 275, 47-53

McArthur, J.M., Donovan, D.I., Thirlwall, M.F., Fouke, B.W., Mattey, D., 2000. Strontium isotope profile of the early Toarcian (Jurassic) oceanic anoxic event, the duration of ammonite biozones, and belemnite palaeotemperatures. Earth Planet. Sci. Lett. 179 269-285

Milkov, A.V., 2004. Global estimates of hydrate-bound gas in marine sediments: how much is really out there? Earth Sci. Rev, 66, 183-197.

Morettini, E., Santantonio, M., Bartolini, A., Cecca, F., Baumgartner, P.O., Hunziker, J.C. 2002. Carbon isotope stratigraphy and carbonate production during the EarlyMiddle Jurassic: examples from the Umbria-Marche-Sabina Apennines (central Italy). Palaeogeogr. PalaeoclimatoL PalaeoecoL 184, 251-273.

Morris, P.H., 1982. Distribution and palaeoecology of Middle Jurassic Foraminifera from the Lower Inferior Oolithe of the Cotswolds. Palaengeogr., Palaeoclimatol, Palaeoecol 37, 319-347.
Morris, P. Coleman, B.E, 1989. The Aalenian to Callovian (Middle Jurassic), In: Jenkins, D.G., Murray, J.W. (Eds.), StratigraphicalAtlas of Fossil Foraminifera, second edition. Ellis Horwood Limited, Chichester, pp. 189-236

NOAA, 2007. http://www.noaa.gov/cgi-biu/oc5/WDA0SF/woa05f.pl

O'Dogherty, L., Sandoval, J., Bartolini, A., Bruchez, S., Bill, M., Guex,J., 2006. Carbon-isotope stratigraphy and ammonite faunal turnover for the Middle Jurassic in the Southern Iberian palaeomargin. Palaeogeogr. PalaeoclimatoL Palaeoecol 239, 311-333.

Osete, M.L., Villalaín, J.J., Osete, C., Gialanella, P.R., 2000. Evolución de Iberia durante el Jurásico a partir de datos paleomagnéticos. Geotemas 1, 117-119.

Payard, J.M., 1947. Les foraminifères du Lias supérieur du Détroit Poitevin. Ph.D Thesis, Fac. Sci. Univ. Paris, France.

Quesada, S. Robles, S., Rosales, I., 2005. Depositional architecture and transgressiveregressive cycles within Liassic backstepping carbonate ramps in the BasqueCantabrian Basin, northern Spain. J. GeoL Soc. London 162, 531-548.

Riegraf, W., 1985. Milef of aune, Biostratigraphie und Fazies im Unteren Toarcium Süwestdeutschlands und Vergleiche mit benachbarten Gebieten. Tübingen MikropaläontoL 3, 1-233.

Rosales, I., Robles, S., Quesada, S., 2001a. Registro de la composición isotópica del Jurásico inferior de la Cuenca Vascocantábrica: metodología analítica y relación con los depósitos orgánicos. Geotemas 3, 61-64.

Rosales, I., Quesada, S., Robles, S., 2001b. Primary and diagenetic isotopic signals in fossils and hemipelagic carbonates: the Lower Jurassic of northern Spain. Sedimentology 48, 1149-1169.

Rosales, I., Robles, S., Quesada, S., 2003. Determinación de las variaciones de la temperatura del agua marina en el Lías en la Cuenca Vasco-Cantábrica mediante la utilización de parámetros geoquímicos $\left(\boldsymbol{~}^{18} \mathrm{O}, \mathrm{Mg} / \mathrm{Ca}, \mathrm{Sr} / \mathrm{C}\right.$ a). Gengaceta $34,79-82$

Rosales, I., Quesada, S., Robles, S., 2004. Paleotemperature variations of Early Jurassic seawater recorded in geochemical trends of belemnites from the BasqueCantabrian basin, northern Spain. Palaeogeogr. Palaeoclimatol Palaeoecol 203, 253-275.

Ruban, D.A., Tyszka, J., 2005. Diversity dynamics and mass extinctions of the EarlyMiddle Jurassic foraminifera: a record from the Northwestern Caucasus. Palaeogeog. Palaeoclimatol Palaeoecol 222, 329-343.

Ruget, C., Cubaynes, R., Nicollin, J.P., Roquet, A.M., 1989. Une méthode de traitement (prélèvement, lavage, tri) pour l'analyse paléoécologique appliquée aux nodosariidés duToarcien des coupes de Penne et de Caylus (Quercy, France). Rev. Micropaléontol $32,45-52$

Sælen, G., Doyle, P., Talbot, M.R., 1996. Stable isotope analyses of belemnite rostra from the Whitby Mudstone Fm., England: surface water conditions during deposition of a marine black shale Palaios 11, $97-117$.

Sandoval, J., O'Dogherty, L., Guex, J., 2001. Evolutionary rates of Jurassic ammonites in relation to sea-level fluctuations. Palaios $16,330-363$

Sandoval, J., O'Dogherty, L., Aguado, R., Bartolini, A., Bruchez, S., Bill, M., 2008. Aalenian carbon-isotope stratigraphy: calibration with ammonite, radiolarian and nannofossil events in the Western Tethys. Palaeogeog. Palaeoclimatol Palaeoecol 267, $115-137$

Schouten, S., van Laam-Peters, H., Rijpstra, W.I.C., Schoell, M., Sinninghe Damste, J., 2000. Effects on an oceanic anoxic event on the stable carbon isotopic composition of Early Toarcian carbon. Am. J. Sci. 300, 1-22.

Sellwood, B.W., Valdes, P.J., 2006. Mesozoic climates: general circulation models and the rock record. Sed. GeoL 190, 269-287.

Serrano Oñate, A., Martínez del Olmo, W., Cámara Rupelo, P., 1989. Diapirismo del Trías salino en el dominio Cántabro-Navarro. Libro homenaje a Rafael Soler. AGGEP, pp. 115-121.

Svensen, H., Planke, S., Chevalier, L., Malthe-Sørensen, A., Corfo, F., Jamtveit, B., 2007. Hidrotermal venting of greenhouse gases triggering Early Jurassic global warming. Earth Planet Sci. Lett. 256, 554-566.

Terquem, O., 1858. Recherches sur les foraminifères du Lias du Département de la Moselle. Mém. Acad. Imper. Metz 39, 563-654

Terquem, $0 ., 1866$. Sixième Mémoire sur les foraminifères du Lias des Départements de l'Indre et de la Moselle. Mém. Acad. Imper. Metz 459-532.

Tripati, A., Elderfield, H., 2005. Deep-sea temperature and circulation changes at the Paleocene-Eocene thermal maximum. Science 308, 1894-1898.

UretaGil, M.S., 1985. Bioestratigrafía yPaleontología (Ammonitina) del Aaleniense en el Sector Noroccidental de la Cordillera Ibérica Colección Tesis Doctorales, Ed. Universidad Complutense de Madrid, 158/85. 452p

Wright, E.K., 1987. Stratification and paleocirculation of the Late Cretaceous Western Interior Seaway of North America. Geol Soc. Am. Bull. 99, 480-490.

Zachos, J.C., Wara, M.W., Bohaty, S., Delaney, M.L., Petrizzo, M.R., Brill, A., Bralower, T.J., Premoli-Silva, I., 2003. A transient rise in tropical sea surface temperatures during the Paleocene-Eocene Thermal Maximum. Science 302,1551-1554. 